\title{
Reversible Oxidation of Myometrial Voltage-Gated Potassium Channels with Hydrogen Peroxide
}

\author{
Isabella Appiah, ${ }^{1}$ Aleksandra Nikolic-Kokic, ${ }^{1}$ Zorana Orescanin-Dusic, ${ }^{1}$ \\ Ratko Radojicic, ${ }^{2}$ Slobodan Milovanovic, ${ }^{3}$ Mihajlo Spasic, ${ }^{1}$ and Dusko Blagojevic ${ }^{1}$ \\ ${ }^{1}$ Department of Physiology, Institute for Biological Research "Sinisa Stankovic," University of Belgrade, 11000 Belgrade, Serbia \\ ${ }^{2}$ Faculty of Biology, University of Belgrade, 11000 Belgrade, Serbia \\ ${ }^{3}$ Faculty of Medicine, University of Eastern Sarajevo, 73300 Foca, Bosnia and Herzegovina
}

Correspondence should be addressed to Isabella Appiah, kuabena@yahoo.com

Received 18 April 2012; Accepted 8 August 2012

Academic Editor: David R. Jones

Copyright (C) 2012 Isabella Appiah et al. This is an open access article distributed under the Creative Commons Attribution License, which permits unrestricted use, distribution, and reproduction in any medium, provided the original work is properly cited.

The uteri, spontaneously active or $\mathrm{Ca}^{2+}(6 \mathrm{mM})$ induced, were allowed to equilibrate, and to inhibit voltage-gated potassium $\left(K_{V}\right)$ channels $1 \mathrm{mM}$ 4-amino pyridine (4-AP) was applied for 15 min before adding $\mathrm{H}_{2} \mathrm{O}_{2} \cdot \mathrm{H}_{2} \mathrm{O}_{2}$ was added cumulatively: $2 \mu \mathrm{M}, 20 \mu \mathrm{M}$, $200 \mu \mathrm{M}, 400 \mu \mathrm{M}$, and $3 \mathrm{mM}$. Average time for $\mathrm{H}_{2} \mathrm{O}_{2}$ concentrations $(2,20,200$, and 400) $\mu \mathrm{M}$ to reach its full effect was 15 min. $\mathrm{H}_{2} \mathrm{O}_{2} 3 \mathrm{mM}$ had a prolonged effect and therefore was left to act for $30 \mathrm{~min}$. Two-way ANOVA showed significant differences in time dependency between spontaneous and $\mathrm{Ca}^{2+}$-induced rat uteri after applying $3 \mathrm{mM} \mathrm{H}_{2} \mathrm{O}_{2}$ (type of contraction, $P=0.0280$ ), but not $400 \mu \mathrm{M} \mathrm{H}_{2} \mathrm{O}_{2}(P=0.9271)$. Our results indicate that $\mathrm{H}_{2} \mathrm{O}_{2}$ oxidises channel intracellular thiol groups and activates the channel, inducing relaxation. Cell antioxidative defence system quickly activates glutathione peroxidase (GSHPx) defence mechanism but not catalase (CAT) defence mechanism. Intracellular redox mechanisms repair the oxidised sites and again establish deactivation of $K_{V}$ channels, recuperating contractility. In conclusion, our results demonstrate that $K_{V}$ channels can be altered in a timedependent manner by reversible redox-dependent intracellular alterations.

\section{Introduction}

Several studies have reported that hydrogen peroxide $\left(\mathrm{H}_{2} \mathrm{O}_{2}\right)$ can mediate smooth muscle relaxation as an endotheliumderived hyperpolarising factor (EDHF) via activation of potassium $\left(\mathrm{K}^{+}\right)$channels [1-4]. Activation of $\mathrm{K}^{+}$channels leads to hyperpolarisation and lowering of the calcium $\left(\mathrm{Ca}^{2+}\right)$ concentration, resulting in a smooth muscle relaxation. To date, several subtypes of $\mathrm{K}^{+}$channels have been identified in the rat uteri smooth muscle. The most abundant and most well studied include large conductance $\mathrm{Ca}^{2+}$ - and voltage-sensitive $\mathrm{K}^{+}$channels $\left(\mathrm{BK}_{\mathrm{Ca}}\right)$, ATP-dependent $\mathrm{K}^{+}$ channels $\left(K_{\mathrm{ATP}}\right)$, voltage-dependent $\mathrm{K}^{+}$channels $\left(K_{V}\right)$, and small-conductance $\mathrm{Ca}^{2+}$-sensitive $\mathrm{K}^{+}$channels (SK). Our previous study showed that $\mathrm{H}_{2} \mathrm{O}_{2}$ induces relaxation in the smooth muscle of rat uteri [5]. In an attempt to identify the signaling pathways used by $\mathrm{H}_{2} \mathrm{O}_{2}$ in this tissue, we then performed a variety of experiments using a range of inhibitors: Nw-nitro-L-arginine methyl ester (L-NAME; NOS inhibitor), methylene blue (MB; cGMP signalling pathway inhibitor), propranolol (non-selective $\beta$-adrenoceptor antagonist), tetraethylammonium (TEA; nonselective $\mathrm{K}^{+}$ channel inhibitor), glibenclamide (selective ATP dependent $\mathrm{K}^{+}$channel inhibitor), and 4-aminopyridine (4-AP; voltagedependent $\mathrm{K}^{+}$channel inhibitor). Our results indicated that $\mathrm{H}_{2} \mathrm{O}_{2}$-induced uterine relaxation is mediated predominantly through $\mathrm{K}^{+}$channels as in the presence of $\mathrm{K}^{+}$channel antagonists, higher doses of $\mathrm{H}_{2} \mathrm{O}_{2}$ were required to reduce uterine contractions compared with L-NAME, MB, and propranolol. The potency order of the $\mathrm{K}^{+}$channels inhibitor effect was 4AP $>$ TEA > glibenclamide (the latter being far less effective), indicating that $K_{V}$ channels play the most significant role of $\mathrm{K}^{+}$channels in $\mathrm{H}_{2} \mathrm{O}_{2}$-induced smooth muscle relaxation of rat uteri [5]. These results were similar to those obtained by other investigators that employed arterial smooth muscles treated with $\mathrm{H}_{2} \mathrm{O}_{2}$ [6]. $K_{V}$ channels are the biggest family 
of potassium channels. They include about 40 members divided in 12 subfamilies, $K_{V} 1-K_{V} 12$, of which $K_{V} 5, K_{V} 6$, $K_{V} 8$, and $K_{V} 9$ are not independently functional, but are $K_{V} 2$ channels modulators. Smith and coworkers showed expression of many $K_{V} \alpha$ subunits in nonpregnant and pregnant mouse myometrium [7]. Opening of $K_{V}$ channels liberates positive charge leading to membrane repolarisation [8] and relaxation. Response to $K_{V}$ channel inhibitor 4-AP disappeared in pregnant myometrium, what was correlated to loss of $K_{V} 4.3 \alpha$ expression [9], what is probably oestrogen dependent [7].

$\mathrm{H}_{2} \mathrm{O}_{2}$ is uncharged oxidant that can diffuse easily trough cell membranes being an eligible signal molecule in many physiological responses. Role of $\mathrm{H}_{2} \mathrm{O}_{2}$ in the regulation of myometrium smooth muscle contractile activity is not fully resolved and is still under investigation. In intact single fibers, there is evidence of complex multifactorial effects in response to $\mathrm{H}_{2} \mathrm{O}_{2}$. For instance, myofibrillar $\mathrm{Ca}^{2+}$ sensitivity increases early during exposure to high $\mathrm{H}_{2} \mathrm{O}_{2}$ concentrations and then declines. Moreover, $\mathrm{H}_{2} \mathrm{O}_{2}$ has little immediate effect on intracellular $\mathrm{Ca}^{2+}$, but prolonged exposure to $\mathrm{H}_{2} \mathrm{O}_{2}$ leads to decreased sarcoplasmic reticulum (SR) $\mathrm{Ca}^{2+}$ reuptake and increased resting $\left(\mathrm{Ca}^{2+}\right)_{\mathrm{i}}$, suggestive of loss of $\mathrm{Ca}^{2+}$ homeostasis [10], also the opening probability of SR $\mathrm{Ca}^{2+}$ release channels increases after thiol oxidation [11]. $\left(\mathrm{Ca}^{2+}\right)_{\mathrm{i}^{-}}$ increase is a constant feature of pathological states associated with oxidative stress [12]. Recent studies have underscored the notion that the $\mathrm{Ca}^{2+}$ and ROS signalling systems are intimately integrated such that $\mathrm{Ca}^{2+}$-dependent regulation of components of ROS homeostasis might influence intracellular redox balance and vice versa [13].

In this study, we have further examined the mechanism of $K_{V}$ channels-dependant $\mathrm{H}_{2} \mathrm{O}_{2}$-relaxing effect on rat smooth muscle contractility and correlated these effects with changes in endogenous antioxidative defence, with respect to two types of activation: spontaneous and calcium-induced.

\section{Material and Methods}

2.1. Experimental System. Isolated uteri from virgin Wistar rats $(200-250 \mathrm{~g})$ in estrous, determined by examination of a daily vaginal lavage [14], were used. All protocols for handling rats were approved by the local ethics committee for animal experimentation that strictly follows international regulations.

\subsection{Isolated Organ Bath Study of Uterine $K_{V}$ Channels Time-} Dependent Inhibition. All rats were killed by cervical dislocation. The uterine horns were rapidly excised and carefully cleaned of surrounding connective tissue and mounted vertically in a $10 \mathrm{ml}$ volume organ bath containing De Jalon's solution aerated with $95 \%$ oxygen and $5 \%$ carbon dioxide at $37^{\circ} \mathrm{C}$.

The uteri, spontaneously active or $\mathrm{Ca}^{2+}(6 \mathrm{mM})$-induced, were allowed to equilibrate at $1 \mathrm{~g}$ tension before addition of the experimental drugs. To inhibit $K_{V}$ channels in uteri $1 \mathrm{mM}$ 4-amino pyridine (4-AP) was applied for $15 \mathrm{~min}$ before adding $\mathrm{H}_{2} \mathrm{O}_{2} \cdot \mathrm{H}_{2} \mathrm{O}_{2}$ was added cumulatively: $2 \mu \mathrm{M}$,
$20 \mu \mathrm{M}, 200 \mu \mathrm{M}, 400 \mu \mathrm{M}$, and $3 \mathrm{mM}$. Myometrial tension was recorded isometrically with a TSZ-04-E isolated organ bath and transducer (Experimetria, Budapest, Hungary). Each $\mathrm{H}_{2} \mathrm{O}_{2}$ concentration was left to act for $15 \mathrm{~min}$ except $3 \mathrm{mM}$ that was left for $30 \mathrm{~min}$.

\subsection{Determination of Uterine Antioxidative Enzyme Activities} after High Impact of $\mathrm{H}_{2} \mathrm{O}_{2}$. To $7 \mathrm{~h}$ contracting uteri were applied $3.6 \mathrm{mM} \mathrm{H}_{2} \mathrm{O}_{2}$ (summed cumulative concentrations from previous experiment). Control group were uteri active equivalent time but untreated. After experiment, samples were immediately frozen, using liquid nitrogen, and then transferred to $-80^{\circ} \mathrm{C}$ until enzyme analysis.

Thawed uteri were homogenised and sonicated in $0.25 \mathrm{M}$ sucrose, $1 \mathrm{mM}$ EDTA, and $0.05 \mathrm{M}$ Tris-HCl buffer $\mathrm{pH} 7.4$ before centrifugation for $90 \mathrm{~min}$ at $105000 \times \mathrm{g}$. The supernatant was used to determine enzyme activities (using a Shimadzu UV-160 spectrophotometer, Shimadzu Scientific Instruments, Shimadzu Corporation, Kyoto, Japan). Superoxide dismutase (SOD) activities were determined by the adrenaline method [15]. One unit of activity is defined as the amount of enzyme necessary to decrease by $50 \%$ the rate of adrenalin autooxidation at $\mathrm{pH}$ 10.2. Manganese SOD (MnSOD) activity was determined by incubating the samples with $8 \mathrm{mM}$ KCN. Copper-zinc SOD (CuZnSOD) activity was calculated as the difference between total SOD and MnSOD activities. The activity of catalase (CAT) was determined by the rate of $\mathrm{H}_{2} \mathrm{O}_{2}$ disappearance measured at $240 \mathrm{~nm}$, according to Claiborne [16]. One unit of CAT activity is defined as the amount of enzyme that decomposes $1 \mathrm{mmol} \mathrm{H}_{2} \mathrm{O}_{2}$ per minute at $25^{\circ} \mathrm{C}$ and $\mathrm{pH}$ 7.0. The activity of glutathione peroxidase (GSHPx) was determined by the GSH-dependent reduction of t-butyl hydroperoxide, using a modification of the assay described by Paglia and Valentine [17]. One unit of GSHPx activity is defined as the amount needed to oxidize $1 \mathrm{nmol} \mathrm{NADPH}$ per min at $25^{\circ} \mathrm{C}$ and $\mathrm{pH}$ 7.0. Glutathione reductase (GR) activity was determined using the method of Glatzle et al. [18]. This assay is based on NADPH oxidation concomitant with GSH reduction. One unit of GR activity is defined as the oxidation of $1 \mathrm{nmol} \mathrm{NADPH}$ per min at $25^{\circ} \mathrm{C}$ and $\mathrm{pH}$ 7.4. All enzyme activities were expressed as units $\cdot \mathrm{mg}^{-1}$ protein.

2.4. Statistical Analyses. Results were analysed with statistical GraphPad Prism (version 5.03), GraphPad Software, San Diego, CA, USA. Statistical significance was determined with $t$-test, one-way ANOVA, and post hoc tests: Dunett-comparison with a control group, Tukey-comparison among all groups and test for linearity trend; two-way ANOVA and post hoc Bonferroni test; regression analysis: Linear regression and nonlinear regression (dose-dependant inhibition model with variable Hill slope).

2.5. Reagents. The following reagents were used: $\mathrm{H}_{2} \mathrm{O}_{2}$ (ZORKA Pharma, Sabac, Serbia); 4-AP (Sigma Chemical Co, St Louis, MO, USA). All were dissolved in distilled water. De Jalon's solution was comprised of (in gl-1): $\mathrm{NaCl} 9.0, \mathrm{KCl}$ $0.42, \mathrm{NaHCO}_{3}$ 0.5, $\mathrm{CaCl}_{2}$ 0.06, and glucose 0.5 . 


\section{Results}

3.1. $\mathrm{K}_{V}$ Channels Dependent $\mathrm{H}_{2} \mathrm{O}_{2}$ Effect on Contractile Activity. Inhibition of $K_{V}$ channels with $1 \mathrm{mM} 4$-amino pyridine (4-AP) increased the basal tonus of uteri contractions (results not shown), confirming the presence of $K_{V}$ channels in the uteri and their role in contractions. After rat uterine $K_{V}$ channels were blocked with $1 \mathrm{mM}$ 4-AP, $\mathrm{H}_{2} \mathrm{O}_{2}(400 \mu \mathrm{M}$ and $3 \mathrm{mM})$ induced effect on contractile activity, both spontaneous and calcium induced. $\mathrm{H}_{2} \mathrm{O}_{2}$ first induced relaxation, after which contractions were gradually recovering. Additionally, $\mathrm{H}_{2} \mathrm{O}_{2} 3 \mathrm{mM}$ had a prolonged effect and therefore was left to act for $30 \mathrm{~min}$. Average time for other $\mathrm{H}_{2} \mathrm{O}_{2}$ concentrations $(2,20,200$, and 400) $\mu \mathrm{M}$ to reach its full effect was $15 \mathrm{~min}$ (Figure 1).

3.2. Time-Dependent Changes in $K_{V}$ Channel Inhibition. One-way ANOVA time-dependence analysis of $\mathrm{H}_{2} \mathrm{O}_{2}$ ( $400 \mu \mathrm{M}$ and $3 \mathrm{mM}$ ) induced effect in spontaneous rat uteri showed time significance (time resp.: $P=0.0246, P<$ $0.0001)$. Post hoc test for linear trend showed significant trend of linear regression $\left(400 \mu \mathrm{M} \mathrm{H}_{2} \mathrm{O}_{2}: r^{2}=0.3031, P=\right.$ 0.0102; 3 mM: $\left.r^{2}=0.8142, P<0.0001\right)$. In $\mathrm{Ca}^{2+}$-induced rat, uteri were also shown significant time dependency and linear trend in the effect of $\mathrm{H}_{2} \mathrm{O}_{2} 3 \mathrm{mM}$ (time: $P<0.0001$; $\left.r^{2}=0.5800, P<0.0001\right)$ but not with $400 \mu \mathrm{M}$ (time: $P=$ 0.6628; linear trend: $r^{2}=0.2673, P=0.3712$ ) (Figure 2).

Two-way ANOVA showed significant differences in time dependency between spontaneous and $\mathrm{Ca}^{2+}$-induced rat uteri after applying $3 \mathrm{mM} \mathrm{H}_{2} \mathrm{O}_{2}$ (type of contraction, $P=$ $0.0280)$, but not $400 \mu \mathrm{M} \mathrm{H}_{2} \mathrm{O}_{2}(P=0.9271)$. Regression analysis of fitted lines also showed similar time dependency but different contraction intensity after applying $3 \mathrm{mM} \mathrm{H}_{2} \mathrm{O}_{2}$ (similar slope, but different intercepts) between spontaneous and $\mathrm{Ca}^{2+}$-induced rat uteri, as well as no significant differences after applying $400 \mu \mathrm{M} \mathrm{H}_{2} \mathrm{O}_{2}$ (no differences in slope and intercepts between spontaneous and $\mathrm{Ca}^{2+}$-induced).

3.3. Changes in Antioxidative Enzyme Activity in Rat Uteri after Impact of $\mathrm{H}_{2} \mathrm{O}_{2}$ High Concentration. $t$-test analysis for changes of antioxidative enzymes activity after applying $3.6 \mathrm{mM} \mathrm{H}_{2} \mathrm{O}_{2}$ (concentration that equals summed cumulative concentrations from previous experiment) comparing to $\mathrm{Ca}^{2+}$-induced uteri active equal time but without $\mathrm{H}_{2} \mathrm{O}_{2}$ treatment showed statistically significant increase of CuZnSOD $(P=0.0381)$ and GSHPx $(P=0.0344)$ activity after impact of $3.6 \mathrm{mM}$ (Figure 3 ).

\section{Discussion}

Earlier studies have shown that $\mathrm{H}_{2} \mathrm{O}_{2}$ can act as contractile and relaxing agent, tissue dependent [19-21], and in some cases, it exhibits a biphasic effect $[2,22]$. Role of $\mathrm{H}_{2} \mathrm{O}_{2}$ in the regulation of myometrial contractile activity is not fully resolved and is still under investigation. In some states as in the thrombosis postpartum [23] or during powerful myometrial contractions that restrict blood flow to the uterus, reperfusion/ischemia injury can occur [21, 24] possibly producing high impact of $\mathrm{H}_{2} \mathrm{O}_{2}$ on the uteri. In our study, we have observed that in $K_{V}$ channel inhibitor (4-AP) pretreated uteri, high concentrations of $\mathrm{H}_{2} \mathrm{O}_{2}$ caused relaxation and recovery independent of the type of contractile activity (spontaneous or calcium induced), just with differences in intensity. Characteristic of this effect was its significant linear time dependency. After the first relaxation effect, there was a time dependent recovery of contractile activity. Additionally at $3 \mathrm{mM} \mathrm{H} \mathrm{H}_{2} \mathrm{O}_{2}$, effect lasted longer (30 min) then the equilibration time for other $\mathrm{H}_{2} \mathrm{O}_{2}$ concentrations ( $15 \mathrm{~min})$. It is known that proteins are $\mathrm{H}_{2} \mathrm{O}_{2}$ targets and that $\mathrm{K}^{+}$channels and proteins that regulate them are redoxsensitive elements [4]. Main protein modifications include direct oxidation, above all amino acids with thiol groups, as cysteine oxidative glication and carbonylation [25-28]. Several electrophysiological studies showed that $\mathrm{H}_{2} \mathrm{O}_{2}$ acts on cysteine of $K_{V}$ modulatory subunits and found specific cysteins that determine the channel sensitivity. Mutation of these cysteins impeded $\mathrm{H}_{2} \mathrm{O}_{2}$-dependent channel activation [29]. After oxidation thiol groups may interact with nearby cysteins forming disulfide bonds [30]. Rogers and coworkers [4] showed that $K_{V}$ channels are regulated in a redox-sensitive manner as $\mathrm{H}_{2} \mathrm{O}_{2}$ 1-10 mM-induced $K_{V}$ currents in coronary artery smooth muscle cells were being antagonized by DTT, a thiol reductant, and blocked by NEM, a thiol-alkylating agent; but they did not observe rapid reversibility (i.e., the effect of $\mathrm{H}_{2} \mathrm{O}_{2}$ to increase $K_{V}$ current was sustained). As a plausible explanation for their result, they suggest that $\mathrm{H}_{2} \mathrm{O}_{2}$ may oxidize an extracellular target, rather than a cytoplasmic one that could be repaired by endogenous intracellular reductants. They based this on the assumption that: (1) $\mathrm{H}_{2} \mathrm{O}_{2}$ crosses membrane easily and has access to extracellular and intracellular thiol groups; (2) thiol groups of extracellular components are always present outside the cell (e.g., extracellular loops of $K_{V}$ channels); (3) intracellular targets include $K_{V}$ channels or proteins that regulate them and always remain inside of the cell; (4) intracellular reductants do not cross the membrane but remain inside the cell having access only to intracellular components. Thus, if an extracellular target was oxidized, no "repair" (i.e., reduction) would be possible. Conversely, if an intracellular target was oxidized, it might be repaired by intracellular reducing mechanisms [4]. We believe that this oxidation could take place intracellular as well, since we did observe time dependent recovery of contractile activity after $\mathrm{H}_{2} \mathrm{O}_{2}$-induced relaxation in the presence of 4-AP. 4-AP blocks $K_{V}$ channels intracellular [31, 32] and has small association and dissociation time (100 ms). 4AP binding on the intracellular side of the $K_{V}$ channel may be temporarily altered due to high concentration of highly diffusible $\mathrm{H}_{2} \mathrm{O}_{2}$. It is possible that $\mathrm{H}_{2} \mathrm{O}_{2}$ oxidises channel intracellular thiol groups and activates the channel, inducing relaxation. However, 4-AP gradually reassociates to intracellular channel sites as intracellular redox mechanisms repair the binding site and again establishes deactivation of $K_{V}$ channels, recuperating contractility. That way $\mathrm{H}_{2} \mathrm{O}_{2}$ could directly interact with $K_{V}$ channels on the intracellular side, but this bond could be overcome with time and 4AP bond reestablished, making the $\mathrm{H}_{2} \mathrm{O}_{2}$ effect transient. Aikawa et al. also observed the transient response to high 


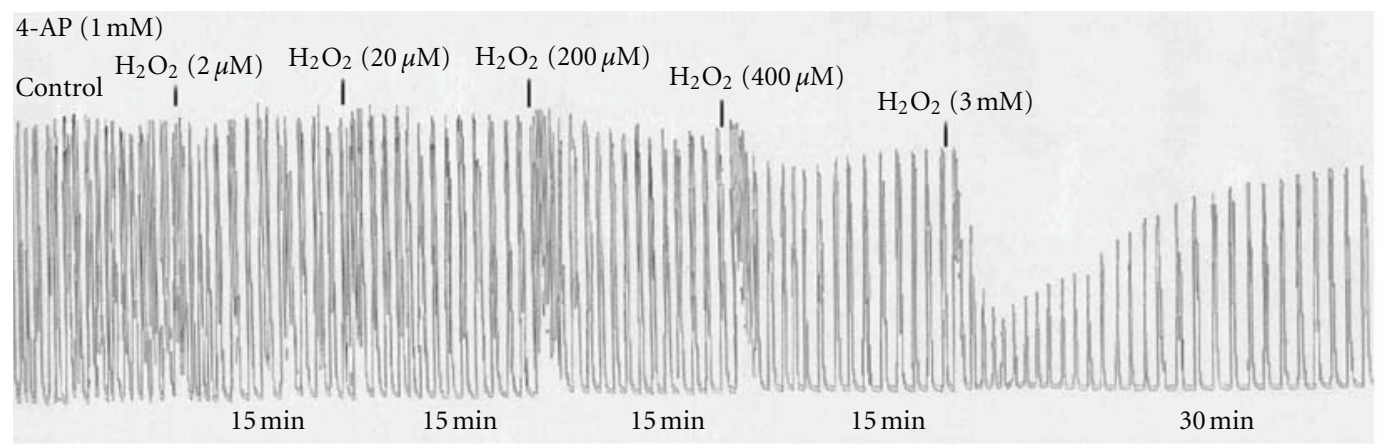

Figure 1: A representative original trace of contractions in rat uteri treated with $\mathrm{H}_{2} \mathrm{O}_{2}(2,20,200,400 \mu \mathrm{M}$, and $3 \mathrm{mM})$ in the presence of 4 -amino pyridine (4-AP). It can be noted the time-dependent recovery of contractions after applying $\mathrm{H}_{2} \mathrm{O}_{2} 400 \mu \mathrm{M}$ and 3 mM, as well as prolonged effect of $3 \mathrm{mM} \mathrm{H}_{2} \mathrm{O}_{2}$.

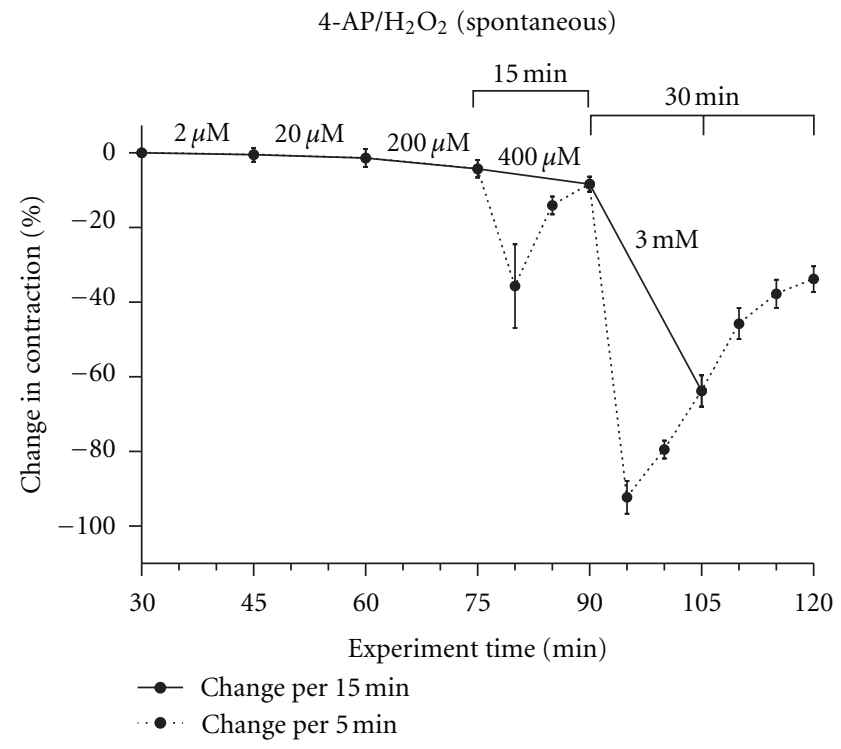

(a)

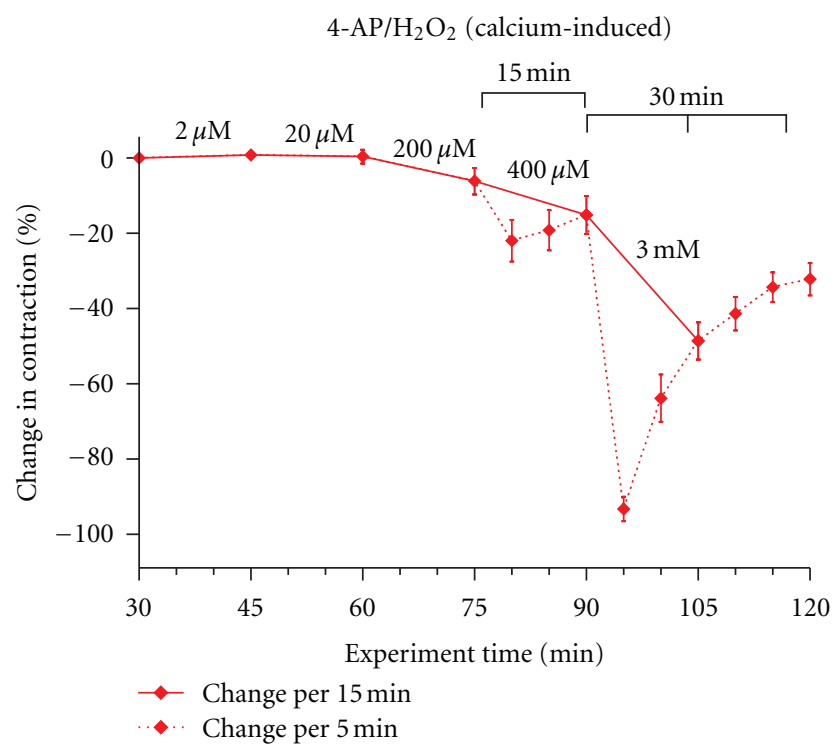

(b)

Figure 2: Time-dependent changes in effect of $\mathrm{H}_{2} \mathrm{O}_{2}(400 \mu \mathrm{M}$ and $3 \mathrm{mM})$ in spontaneous (a) and $\mathrm{Ca}^{2+}$-induced, (b) rat uteri contractile activity in the presence of $K_{V}$ channel inhibitor, 4-AP $1 \mathrm{mM}$. Contractile activity is expressed as change in contraction amplitude (\%) after applying $\mathrm{H}_{2} \mathrm{O}_{2}$. Full line represents amplitude changes on every $15 \mathrm{~min}$ and dotted line on every 5 min after applying $\mathrm{H}_{2} \mathrm{O}_{2}(400 \mu \mathrm{M}$ and $3 \mathrm{mM}$ ). $3 \mathrm{mM} \mathrm{H}_{2} \mathrm{O}_{2}$ had prolonged effect (time for contractions to equilibrate: $30 \mathrm{~min}$ ). Values are expressed as mean \pm error. $x$-axis represents the full experiment time starting from $30 \mathrm{~min}$, which is the uteri equilibration interval.

$\mathrm{H}_{2} \mathrm{O}_{2}$ concentrations in time. They showed that after $1 \mathrm{~h}$ of exposure to 6 different concentrations of $\mathrm{H}_{2} \mathrm{O}_{2}(0 \%$, $0.0625 \%, 0.125 \%, 0.25 \%, 0.5 \%$, and $1 \%$ ), the contractile response of rat bladder smooth muscle decreased progressively to increase in $\mathrm{H}_{2} \mathrm{O}_{2}$ concentration [33]. In more recent study, Han at al. also found that increasing the duration of treatment with $3 \times 10^{-4} \mathrm{~g} \% \mathrm{H}_{2} \mathrm{O}_{2}$ progressively decreased the contractile responses of the smooth muscle of bladder [34].

With an increase in $\mathrm{H}_{2} \mathrm{O}_{2}$, its toxic effect starts to appear. Therefore, timely elimination of messengers is important in cell signalisation. In our study after applying high concentration of $\mathrm{H}_{2} \mathrm{O}_{2}(3.6 \mathrm{mM})$ on a long-term activity, we observed increase in CuZnSOD and GSHPx activity. $\mathrm{H}_{2} \mathrm{O}_{2}$ is mainly scavenged by CAT and GSHPx. CuZnSOD, is a cytoplasmic $\mathrm{O}_{2}{ }^{\cdot-}$ scavenger, and as such implies $\mathrm{O}_{2}{ }^{\cdot-}$ increased production. Some researchers also showed that $\mathrm{H}_{2} \mathrm{O}_{2}$ causes increase in $\mathrm{O}_{2}{ }^{--}$[35]. Others have observed decrease of reduced form of glutathione, a necessary factor in GSHPx activity [36]. As mentioned previously, we have observed increased activity of GSHPx, $\mathrm{H}_{2} \mathrm{O}_{2}$ scavenger. However, other important $\mathrm{H}_{2} \mathrm{O}_{2}$ scavenger, $\mathrm{CAT}$, did not show any changes. It seems that cell antioxidative defence system quickly activates GSHPx defence mechanism but not CAT defence mechanism. CAT is mainly active in peroxisome though some of its activity is also present in mitochondria and endoplasmatic reticulum. CAT, comparing to GSHPx, has lesser affinity for $\mathrm{H}_{2} \mathrm{O}_{2}$ and as such is not effective in scavenging low concentrations of $\mathrm{H}_{2} \mathrm{O}_{2}[37,38]$. Therefore, GSHPx is considered as a $\mathrm{H}_{2} \mathrm{O}_{2}$ low concentration scavenger. However, it was shown that CAT is also active at $\mathrm{H}_{2} \mathrm{O}_{2}$ lower 


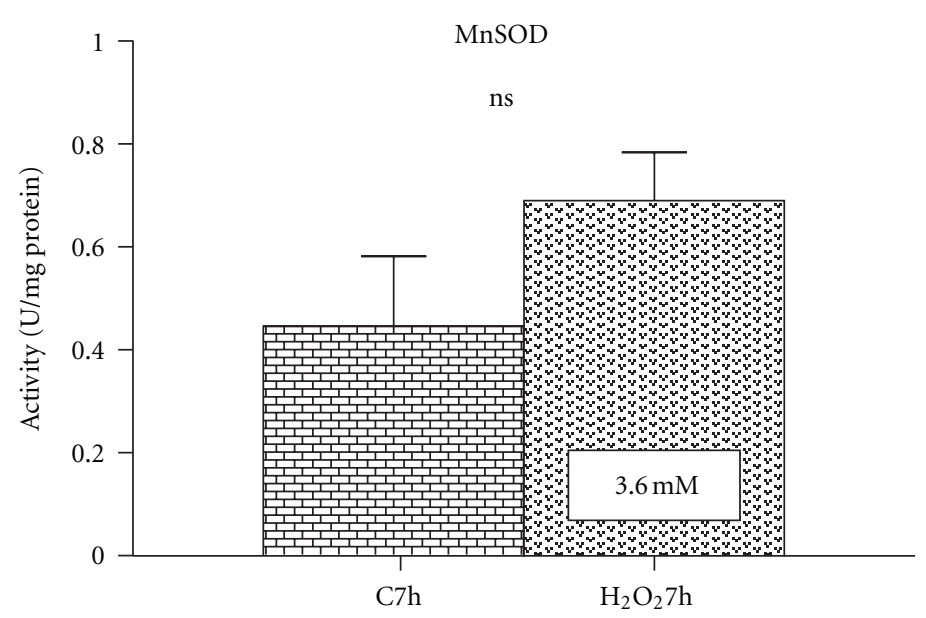

(a)

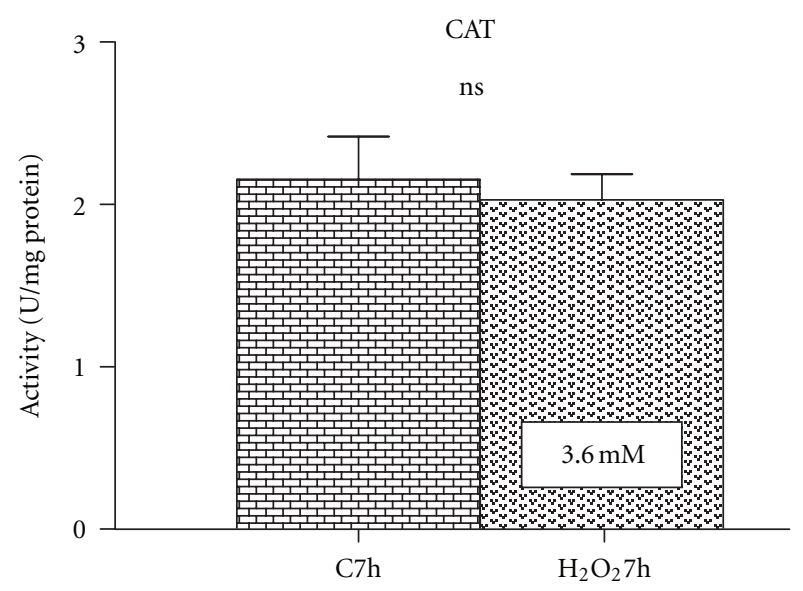

(c)

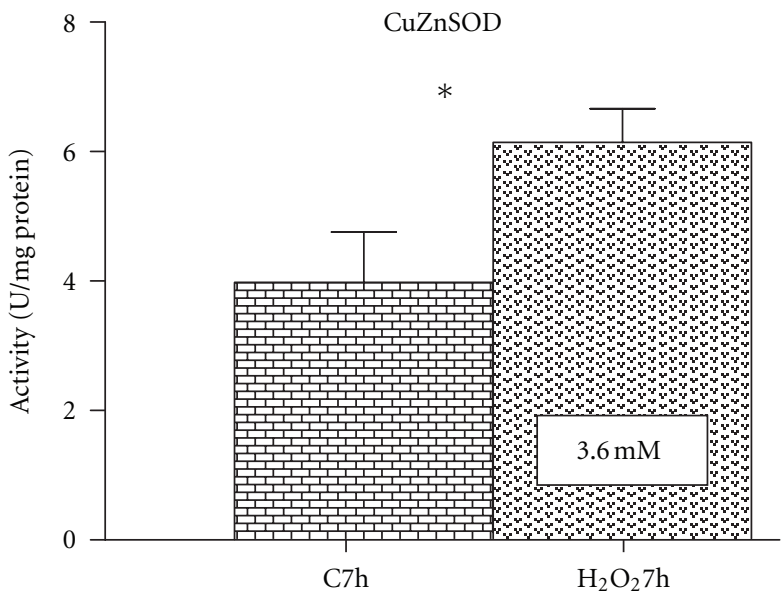

(b)

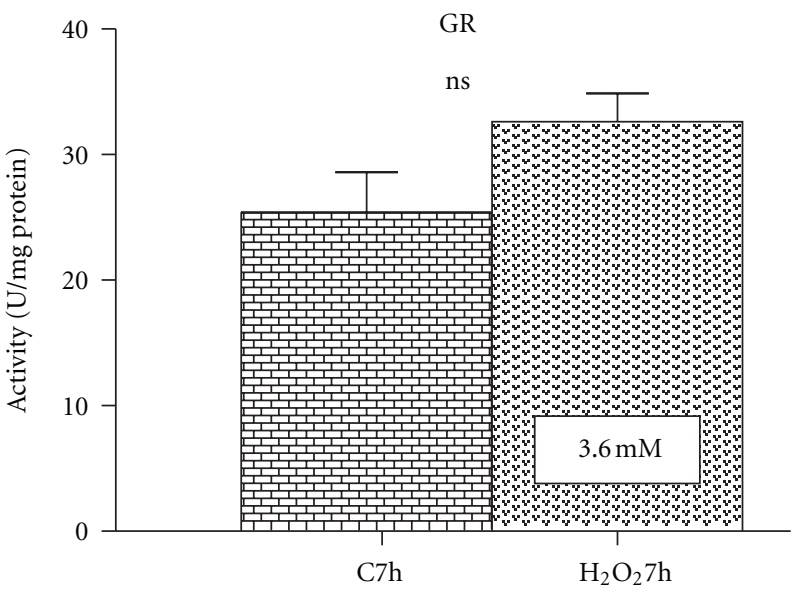

(d)

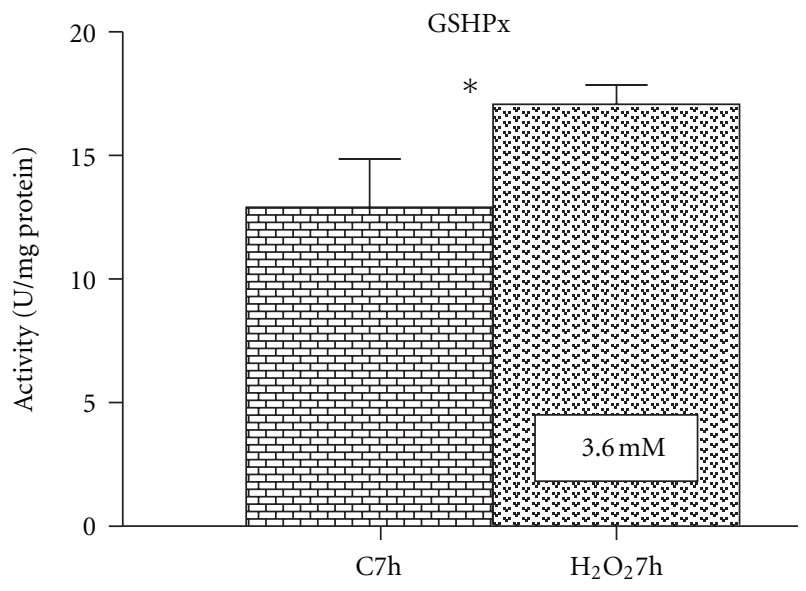

(e)

FIGURe 3: Change of AOS enzyme activity (MnSOD (a), CuZnSOD (b), CAT (c), GR (d), and GSHPx (e)) in Ca ${ }^{2+}$-induced rat uteri after applying $3.6 \mathrm{mM} \mathrm{H} \mathrm{H}_{2}$. Control group were uteri active equivalent time interval without $\mathrm{H}_{2} \mathrm{O}_{2}$ treatment. Data are expressed as mean \pm error. Groups were compared with $t$-test $\left(P<0.05\right.$, significant). Ns: non significant; ${ }^{*} P<0.05$. 
concentrations and that it loses its activity at $\mathrm{H}_{2} \mathrm{O}_{2}$ higher concentrations $[39,40]$, what is implying to a possible cause of the absence in its activity in our study.

In conclusion, our results demonstrate that $K_{V}$ channels can be altered in a time-dependent manner by possible time and redox-dependent alterations of $K_{V}$ channels intracellular binding sites or proteins that regulate them and that GSHPx mechanism is the primary scavenging mechanism in this $\mathrm{H}_{2} \mathrm{O}_{2}$ conditions. Further studies may help to find the possible solutions in protecting myometrium in pathological states including strong redox impact on the cell, as reperfusion ischemia or thrombosis postpartum.

\section{References}

[1] R. S. Barlow, A. M. El-Mowafy, and A. R. E. White, " $\mathrm{H}_{2} \mathrm{O}_{2}$ opens $\mathrm{BK}(\mathrm{Ca})$ channels via the PLA2-arachidomic acid signaling cascade in coronary artery smooth muscle," American Journal of Physiology, vol. 279, no. 2, pp. H475-H483, 2000.

[2] Y. J. Gao, S. Hirota, D. W. Zhang, L. J. Janssen, and R. M. K. W. Lee, "Mechanisms of hydrogen-peroxide-induced biphasic response in rat mesenteric artery," British Journal of Pharmacology, vol. 138, no. 6, pp. 1085-1092, 2003.

[3] Y. Iida, Z. S. Katusic, and E. P. Wei, "Mechanisms of cerebral arterial relaxations to hydrogen peroxide," Stroke, vol. 31, no. 9, pp. 2224-2230, 2000.

[4] P. A. Rogers, W. M. Chilian, I. N. Bratz, R. M. Bryan, and G. M. Dick, " $\mathrm{H}_{2} \mathrm{O}_{2}$ activates redox- and 4-aminopyridine-sensitive $\mathrm{Kv}$ channels in coronary vascular smooth muscle," American Journal of Physiology, vol. 292, no. 3, pp. H1404-H1411, 2007.

[5] I. Appiah, S. Milovanovic, R. Radojicic et al., "Hydrogen peroxide affects contractile activity and anti-oxidant enzymes in rat uterus," British Journal of Pharmacology, vol. 158, no. 8, pp. 1932-1941, 2009.

[6] P. A. Rogers, G. M. Dick, J. D. Knudson et al., " $\mathrm{H}_{2} \mathrm{O}_{2}$-induced redox-sensitive coronary vasodilation is mediated by 4 -aminopyridine-sensitive K+ channels," American Journal of Physiology, vol. 291, no. 5, pp. H2473-H2482, 2006.

[7] R. C. Smith, M. C. McClure, M. A. Smith, P. W. Abel, and M. E. Bradley, "The role of voltage-gated potassium channels in the regulation of mouse uterine contractility," Reproductive Biology and Endocrinology, vol. 5, no. 5, article 41, 2007.

[8] H. Wulff, N. A. Castle, and L. A. Pardo, "Voltage-gated potassium channels as therapeutic targets," Nature Reviews Drug Discovery, vol. 8, no. 12, pp. 982-1001, 2009.

[9] M. Song, G. Helguera, M. Eghbali et al., "Remodeling of Kv4.3 Potassium Channel Gene Expression under the Control of Sex Hormones," The Journal of Biological Chemistry, vol. 276, no. 34, pp. 31883-31890, 2001.

[10] F. H. Andrade, M. B. Reid, D. G. Allen, and H. Westerblad, "Effect of hydrogen peroxide and dithiothreitol on contractile function of single skeletal muscle fibres from the mouse," Journal of Physiology, vol. 509, no. 2, pp. 565-575, 1998.

[11] B. Aghdasi, J. Z. Zhang, Y. Wut, M. B. Reid, and S. L. Hamilton, "Multiple classes of sulfhydryls modulate the skeletal muscle $\mathrm{Ca}^{2+}$ release channel," The Journal of Biological Chemistry, vol. 272, no. 6, pp. 3739-3748, 1997.

[12] C. Camello-Almaraz, P. J. Gomez-Pinilla, M. J. Pozo, and P. J. Camello, "Mitochondrial reactive oxygen species and $\mathrm{Ca}^{2+}$ signaling," American Journal of Physiology, vol. 291, no. 5, pp. C1082-C1088, 2006.
[13] Y. Yan, C. L. Wei, W. R. Zhang, H. P. Cheng, and J. Liu, "Crosstalk between calcium and reactive oxygen species signaling," Acta Pharmacologica Sinica, vol. 27, no. 7, pp. 821-826, 2006.

[14] F. K. Marcondes, F. J. Bianchi, and A. P. Tanno, "Determination of the estrous cycle phases of rats: some helpful considerations," Brazilian Journal of Biology, vol. 62, no. 4, pp. 609-614, 2002.

[15] H. P. Misra and I. Fridovich, "The role of superoxide anion in the autoxidation of epinephrine and a simple assay for superoxide dismutase," The Journal of Biological Chemistry, vol. 247, no. 10, pp. 3170-3175, 1972.

[16] “Assay for catalase," in Handbook of Methods for Oxygen Radical Research, A. Claiborne, Ed., pp. 283-284, CRC Press, Boca Raton, Fla, USA, 1985.

[17] D. E. Paglia and W. N. Valentine, "Studies on the quantitative and qualitative characterization of erythrocyte glutathione peroxidase," The Journal of Laboratory and Clinical Medicine, vol. 70, no. 1, pp. 158-169, 1967.

[18] D. Glatzle, J. P. Vuilleumier, F. Weber, and K. Decker, "Glutathione reductase test with whole blood, a convenient procedure for the assessment of the riboflavin status in humans," Experientia, vol. 30, no. 6, pp. 665-667, 1974.

[19] Y. J. Gao and R. M. K. W. Lee, "Hydrogen peroxide is an endothelium-dependent contracting factor in rat renal artery," British Journal of Pharmacology, vol. 146, no. 8, pp. 1061-1068, 2005.

[20] J. Gil-Longo and C. González-Vázquez, "Characterization of four different effects elicited by $\mathrm{H}_{2} \mathrm{O}_{2}$ in rat aorta," Vascular Pharmacology, vol. 43, no. 2, pp. 128-138, 2005.

[21] A. Y. Warren, B. Matharoo-Ball, R. W. Shaw, and R. N. Khan, "Hydrogen peroxide and superoxide anion modulate pregnant human myometrial contractility," Reproduction, vol. 130, no. 4, pp. 539-544, 2005.

[22] P. A. Lucchesi, S. Belmadani, and K. Matrougui, "Hydrogen peroxide acts as both vasodilator and vasoconstrictor in the control of perfused mouse mesenteric resistance arteries," Journal of Hypertension, vol. 23, no. 3, pp. 571-579, 2005.

[23] M. R. Toglia and T. E. Nolan, "Venous thromboembolism during pregnancy: a current review of diagnosis and management," Obstetrical and Gynecological Survey, vol. 52, no. 1, pp. 60-72, 1997.

[24] A. Nakai, A. Oya, H. Kobe et al., "Changes in maternal lipid peroxidation levels and antioxidant enzymatic activities before and after delivery," Journal of Nippon Medical School, vol. 67, no. 6, pp. 434-439, 2000.

[25] K. England and T. G. Cotter, "Direct oxidative modifications of signalling proteins in mammalian cells and their effects on apoptosis," Redox Report, vol. 10, no. 5, pp. 237-245, 2005.

[26] I. Dalle-Donne, G. Aldini, M. Carini, R. Colombo, R. Rossi, and A. Milzani, "Protein carbonylation, cellular dysfunction, and disease progression," Journal of Cellular and Molecular Medicine, vol. 10, no. 2, pp. 389-406, 2006.

[27] W. F. Graier and M. Hecker, "Endothelial $\mathrm{H}_{2} \mathrm{O}_{2}$ : a bad guy turning good?" Arteriosclerosis, Thrombosis, and Vascular Biology, vol. 28, no. 10, pp. 1691-1693, 2008.

[28] C. M. Wong, A. K. Cheema, L. Zhang, and Y. J. Suzuki, "Protein carbonylation as a novel mechanism in redox signaling," Circulation Research, vol. 102, no. 3, pp. 310-318, 2008.

[29] Z. Wang, J. Kiehn, Q. Yang, A. M. Brown, and B. A. Wible, "Comparison of binding and block produced by alternatively spliced $\mathrm{Kv} \beta 1$ subunits," The Journal of Biological Chemistry, vol. 271, no. 45, pp. 28311-28317, 1996.

[30] H. J. Forman, J. M. Fukuto, and M. Torres, "Redox signaling: thiol chemistry defines which reactive oxygen and nitrogen 
species can act as second messengers," American Journal of Physiology, vol. 287, no. 2, pp. C246-C256, 2004.

[31] N. A. Castle, S. R. Fadous, D. E. Logothetis, and G. K. Wang, "4-Aminopyridine binding and slow inactivation are mutually exclusive in rat Kv1.1 and Shaker potassium channels," Molecular Pharmacology, vol. 46, no. 6, pp. 1175-1181, 1994.

[32] J. A. Yao and G. N. Tseng, "Modulation of 4-AP block of a mammalian A-type $\mathrm{K}$ channel clone by channel gating and membrane voltage," Biophysical Journal, vol. 67, no. 1, pp. 130-142, 1994.

[33] K. Aikawa, R. E. Leggett, and R. M. Levin, "Effect of age on hydrogen peroxide mediated contraction damage in the male rat bladder," Journal of Urology, vol. 170, no. 5, pp. 2082-2085, 2003.

[34] J. H. Han, M. Y. Lee, S. Y. Lee et al., "Effect of low concentrations of hydrogen peroxide on the contractile responses of rat detrusor smooth muscle strips," European Journal of Pharmacology, vol. 638, no. 1-3, pp. 115-120, 2010.

[35] C. H. Coyle, L. J. Martinez, M. C. Coleman, D. R. Spitz, N. L. Weintraub, and K. N. Kader, "Mechanisms of $\mathrm{H}_{2} \mathrm{O}_{2}$-induced oxidative stress in endothelial cells," Free Radical Biology and Medicine, vol. 40, no. 12, pp. 2206-2213, 2006.

[36] P. K. Witting, H. H. Harris, B. S. Rayner et al., "The endothelium-derived hyperpolarizing factor, $\mathrm{H}_{2} \mathrm{O}_{2}$, promotes metalion efflux in aortic endothelial cells: elemental mapping by a hard X-ray microprobe," Biochemistry, vol. 45, no. 41, pp. 12500-12509, 2006.

[37] P. Saltman, "Oxidative stress: a radical review," Seminars in Hematology, vol. 26, no. 4, pp. 249-256, 1989.

[38] S. G. Rhee, K. S. Yang, S. W. Kang, H. A. Woo, and T. S. Chang, "Controlled elimination of intracellular $\mathrm{H}_{2} \mathrm{O}_{2}$ : regulation of peroxiredoxin, catalase, and glutathione peroxidase via posttranslational modification," Antioxidants and Redox Signaling, vol. 7, no. 5-6, pp. 619-626, 2005.

[39] O. M. Lardinois, M. M. Mestdagh, and P. G. Rouxhet, "Reversible inhibition and irreversible inactivation of catalase in presence of hydrogen peroxide," Biochimica et Biophysica Acta, vol. 1295, no. 2, pp. 222-238, 1996.

[40] C. Cao, Y. Leng, and D. Kufe, "Catalase activity is regulated by c-Abl and Arg in the oxidative stress response," The Journal of Biological Chemistry, vol. 278, no. 32, pp. 29667-29675, 2003. 


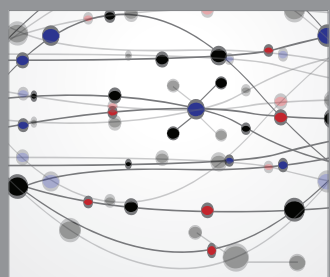

The Scientific World Journal
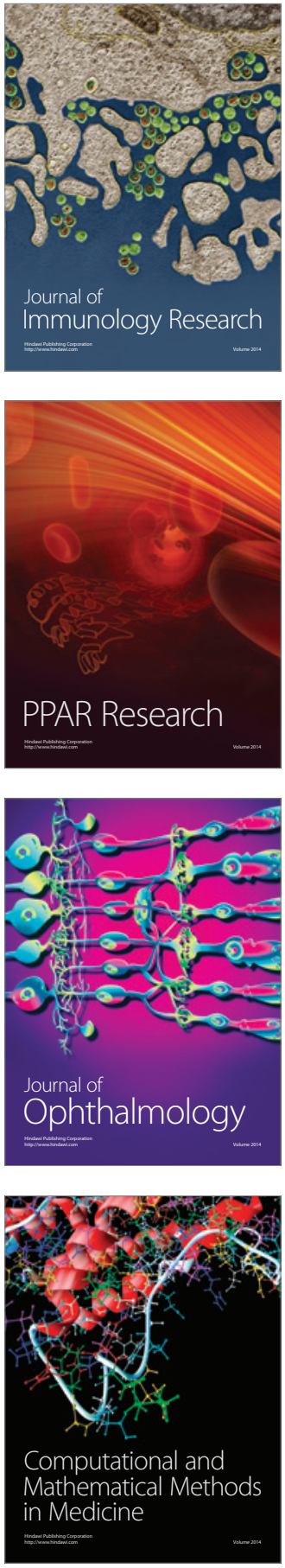

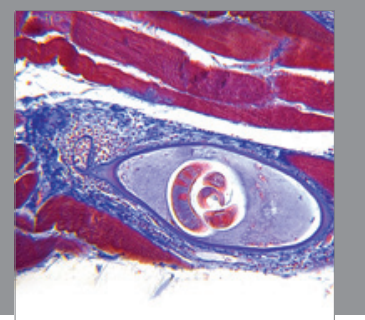

Gastroenterology

Research and Practice
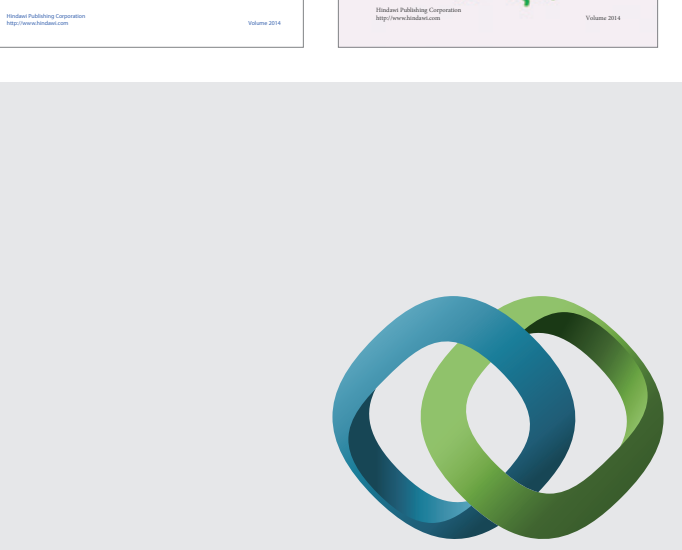

\section{Hindawi}

Submit your manuscripts at

http://www.hindawi.com
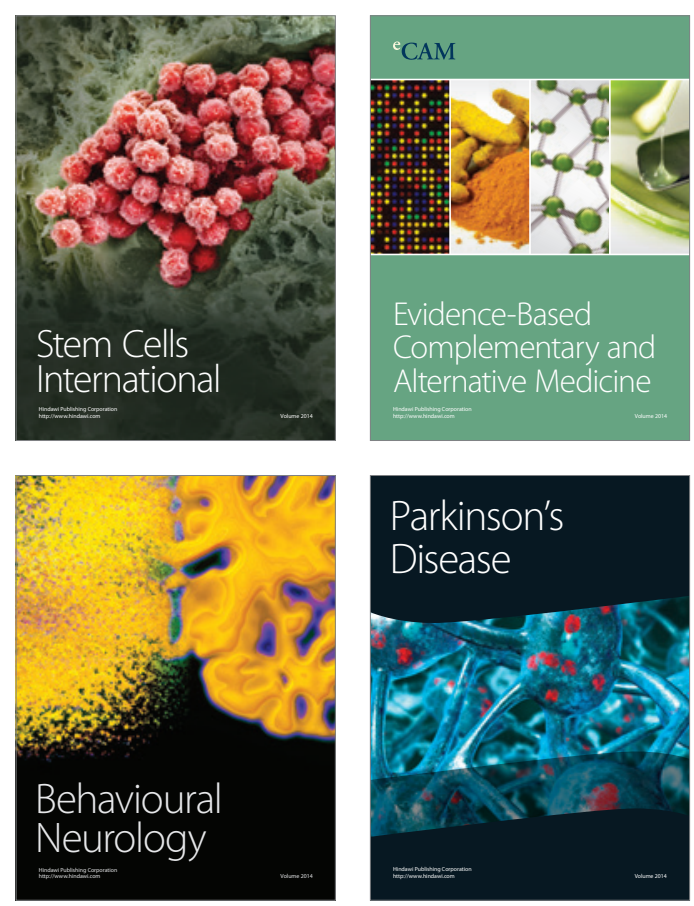

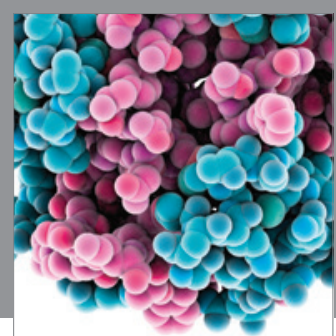

Journal of
Diabetes Research

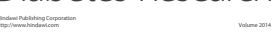

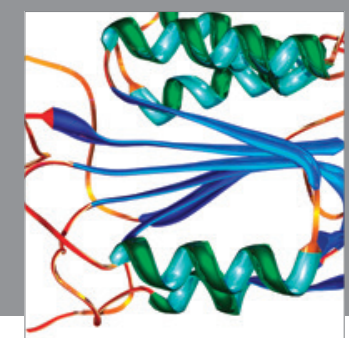

Disease Markers
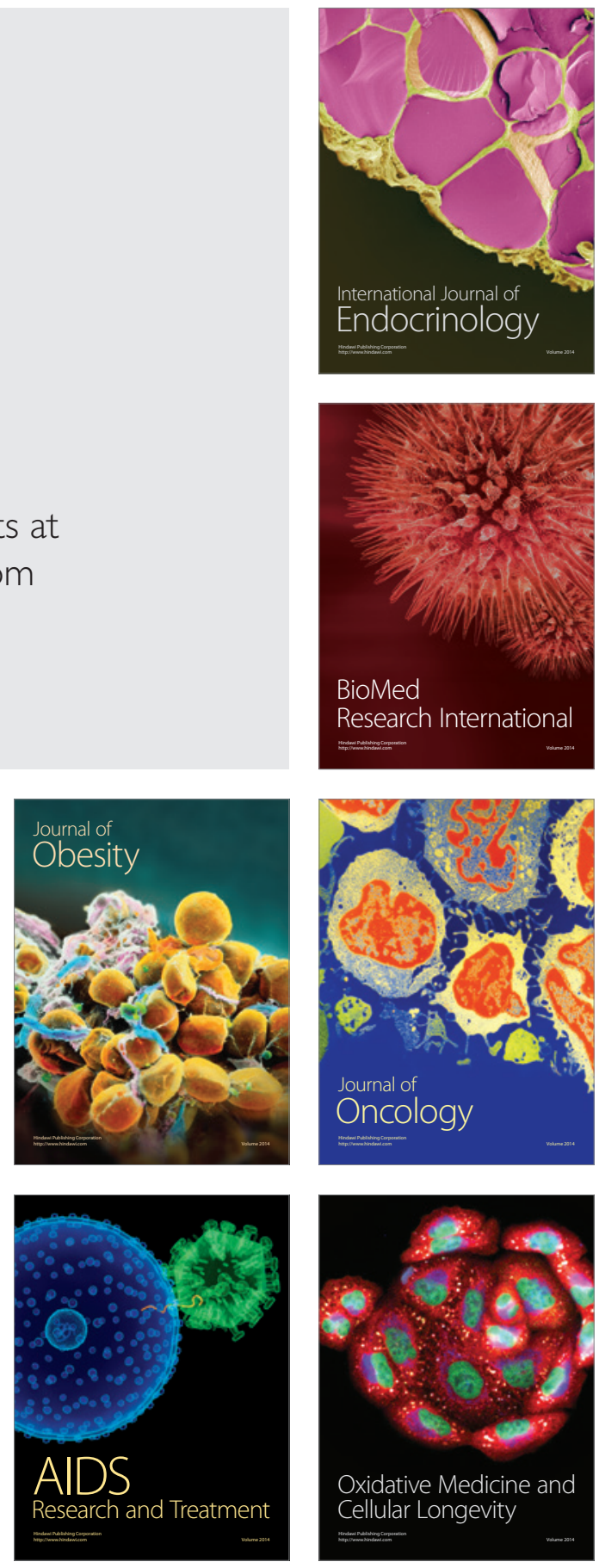